ECONOMIC, INDUSTRIAL AND MANAGERIAL

COORDINATION BETWEEN JAPAN AND THE USA 


\section{Economic, Industrial and Managerial Coordination between Japan and the USA}

Edited by

Kiyoshi Abe

Professor of International Economics

Chiba University, Japan

\section{William Gunther}

Professor of Economics

University of Alabama, Tuscaloosa, USA

and

\section{Harold See}

Professor of Law

University of Alabama, Tuscaloosa, USA

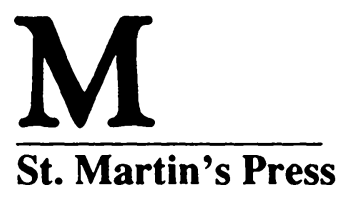


(c) Kiyoshi Abe, William Gunther and Harold See 1992

Softcover reprint of the hardcover 1st edition 1992 978-0-333-55242-1

All rights reserved. No reproduction, copy or transmission of this publication may be made without written permission.

No paragraph of this publication may be reproduced, copied or transmitted save with written permission or in accordance with the provisions of the Copyright, Designs and Patents Act 1988, or under the terms of any licence permitting limited copying issued by the Copyright Licensing Agency, 90 Tottenham Court Road, London WIP 9HE.

Any person who does any unauthorised act in relation to this publication may be liable to criminal prosecution and civil claims for damages.

First published in Great Britain 1992 by

THE MACMILLAN PRESS LTD

Houndmills, Basingstoke, Hampshire RG21 2XS

and London

Companies and representatives

throughout the world

A catalogue record for this book is available

from the British Library

ISBN 978-1-349-22447-0

DOI 10.1007/978-1-349-22445-6

First published in the United States of America 1992 by

Scholarly and Reference Division,

ST. MARTIN'S PRESS, INC.,

175 Fifth Avenue,

New York, N.Y. 10010

ISBN 978-0-312-07987-1

Library of Congress Cataloging-in-Publication Data

Economic, industrial, and managerial coordination between Japan and the USA / edited by Kiyoshi Abe, William Gunther, and Harold See.

p. $\mathrm{cm}$.

Papers presented at a conference held at the East-West Center in 1990, and sponsored by the Chiba University and University of Alabama, Tuscaloosa.

Includes index.

ISBN 978-0-312-07987-1

1. United States-Foreign economic relations-Japan-Congresses.

2. Japan-Foreign economic relations-United States-Congresses.

3. Industrial management-Japan-Congresses. 4. Industrial

management-United States-Congresses. I. Abe, Kiyoshi, 1939- .

II. Gunther, William, 1940 - III. See, Harold, 1943- .

IV. Chiba Daigaku. V. University of Alabama.

HF3127.E35 1992

$337.52073-\mathrm{dc} 20$ 


\section{Contents}

First Foreword by Yasuhiko Yuize, Dean, College of Law and Economics, Chiba University

Second Foreword by J. Barry Mason, Dean, College of

Commerce and Business Administration, The University of Alabama

Third Foreword by Seiji Nay'a, East-West Center and University' of Hawaii

Acknowledgements

Notes on the Contributors

Introduction by Kiyoshi Abe, William Gunther and Harold See

\section{PART I ECONOMIC ISSUES}

1 Barriers to Trade Negotiation Harmony: Cultural Contradictions

Lawrence $W$. Foster

2 Japanese Direct Investment in the USA: Direct Investment, Hollowing-Out and Deindustrialization

Kiyoshi Abe

3 US Deindustrialization and Pacific Imports

David Cheng, William D. Gunther and Kiyoshi Abe

4 International Monetary Policy Coordination: Tests of a Nominal Targeting Proposal

Donald L. Hooks

5 Monetary and Fiscal Policy Coordination: Japan and the USA

Kenji Komatsu

6 Household Saving Rate: Impact of Retirement Plan

Participation

Mohamed Abdel-Ghany, Deanna L. Sharpe and Hisayo Shima

7 Development Assistance: US-Japan Economic Cooperation Shiqeyuki Abe and Bruce Koppel 


\section{PART II INDUSTRIAL AND MANAGERIAL ISSUES}

8 Transfer of Japanese Company Culture Motofusa Murayama

9 Japanese Corporate English Training Chadwick B. Hilton

10 Telecommunications Trade Friction Meheroo Jussawalla and Barbara Ross-Pfeiffer

11 Economic Incentives and Computer Software: A Comparative Analysis of Intellectual Property Law Harold See with the assistance of Rebecca Copeland

12 Property Rights in Computer Software: The Japan-US Framework as an International Standard Sumner J. La Croix

13 Steel Restructuring in Japan and the USA Trevor Bain

14 Import Liberalization and Domestic Beef: A Simulation based on an Econometric Model

Yasuhiko Yuize

15 Auto Industry Human Resource Strategies: The US

Response to Japanese Competition

James Cashman

\section{PART III CONCLUSION}

16 An Overview of Coordination Concerns

Kiyoshi Abe, William Gunther and Harold See

Appendix A US-Japan Relations in the 1990s

Charles E. Morrison

Appendix $B$ The CHIBAMA Project

Marilyn B. Emplaincourt

Index 


\section{First Foreword}

Faced in 1988 with increasing economic conflict between Japan and the US, I felt that we as social scientists should attempt to decrease the tensions and contribute to the solution of the problem. Within my department of law and economics, we thought about our collegial and institutional relationships in the US. Specifically, we thought about our sister-university relationship with the University of Alabama located in Tuscaloosa since 1831 . We realized that although Chiba University and the University of Alabama had a four-year-old formal relationship, faculty members of our two institutions had never conducted official joint research together. Our department of economics, therefore, asked the Japanese Ministry of Education (Monbusho) to support and sponsor joint research with our counterpart in Alabama. Fortunately, Monbusho gave us support for three years (1988-90) and thereby established a precedent in its traditional budgetary system. We interpret the actions of Monbusho as an indication that we at Chiba University were already able to contribute in some small way to a solution to the conflict.

The indirect effects of our joint research cooperation with the University of Alabama touch not only the governments of our two countries but also the localization process of globalization at the community level in Chiba prefecture and the state of Alabama. For example, there is no American who does not know Tokyo and many Americans have heard of the "Keiyou" (pronounced "Kay-yo") Industrial Belt of factories located on Tokyo Bay. Chiba City, on the other hand, is not well known in the USA even though it is located less than an hour by train from Tokyo ("KEI") and Chiba ("YOU"). By the same token, many Japanese have seen Western movies with their cowboys and Indians as well as the film Gone with the Wind with its portrayal of Atlanta and the Old South. One of our American friends has even told us that Tuscaloosa is the name of a famous brave Indian chief and means "Black Warrior". Nevertheless, most Japanese don't know where Tuscaloosa is even though they may have been to Atlanta.

Through the joint cooperation project of Chiba University and the University of Alabama researchers at both institutions have been able to enjoy at the local level learning in their respective academic fields, living and leisure, if only for a few days. The three L's - learning, living and leisure - in Chiba City and Tuscaloosa are useful and instructive to both the faculty members and local residents of both cities in deepening our mutual understanding about the differences and similarities of the 
structures of Japan and the USA. Enhanced understanding is a great and significant indirect contribution of our project to decreasing tensions between the governments and people of both countries.

In 1990, the final year of the project, the coordinators at Chiba University and the University of Alabama decided to hold the last conference in Hawaii given its location as midway between the cities of Chiba and Tuscaloosa. The staff and researchers of the East-West Center not only provided us with all conference facilities but also actively participated in presenting research papers. Thus, the EastWest Center served as a bridge over the Pacific Ocean from which we could draw a connecting line from Chiba to Tuscaloosa. And now Macmillan has given us the opportunity to publish the results of our cooperation. We hope the publication will enable us to expand the line over the Pacific further into space and the globalization of our coordination.

I sincerely appreciate all the individuals who have contributed to the resolution of Japan-US conflicts by committing themselves directly and indirectly to our work and efforts.

YASUhiko YuIZE

Dean, Faculty of Law and Economics

Chiba University, Japan 


\section{Second Foreword}

The ongoing formal relationship between Chiba University and the University of Alabama, with collaborative faculty research, faculty and student exchanges, and executive development programs, represents the type of joint venture that major American business schools increasingly will use to broaden their global ties. This program is one part of a multifaceted approach by the University of Alabama for strengthening its ties with the Pacific rim and, especially, Japan.

Our College of Commerce has been enriched by the presence of distinguished visiting Japanese economists from Chiba University for periods of time ranging from one semester to a full academic year. Yoshimasa Nomura and Kiyoshi Abe have been valued visitors already, and they will be succeeded by Eiichi Akimoto. These colleagues have provided valuable insights for curriculum revision, outstanding classroom instruction, and invaluable collaborative research on topics of mutual interest.

The diversity of subject matter addressed in the papers published in this text is impressive. Subject areas include communication, corporate culture and leadership styles, trade relations, consumer and corporate finance, development economics, and related subject areas. The collaborative partnerships in preparing these papers proved to be an enriching experience for faculty members at both the University of Alabama and Chiba University. Additionally, the opportunity for extended onsite visits by various faculty members at their partner's campus and the opportunity to spend time at the East-West Center further enriched the perspectives of the participants and helped to hone the insights and observations which have significance both for corporate management and for advancing the body of knowledge of the respective disciplines.

We expect the relationship between Chiba University and the University of Alabama to continue to grow in depth, complexity and maturity. The collaboration has contributed to a measurable improvement in quality of education for students and in a broadening of perspective for faculty members.

We extend our deep appreciation to Chiba University for the willingness to enter into this partnership and for being such a gracious host. We also extend our appreciation to the personnel of the East-West Center for their support and encouragement.

J. Barry Mason

Dean, College of Commerce and Business Administration, University of Alabama 


\section{Third Foreword}

This book and the conference on which it was based address a complex issue of the utmost importance: the US-Japan relationship. The papers presented here focus on the crucial economic issues that are at the core of the US-Japan relationship. The East-West Center was pleased to cosponsor the conference with Chiba University and the University of Alabama and we are confident that the papers presented in this volume will make a thoughtful contribution to the understanding of these important issues.

What is especially appealing about the conference papers presented here is that they contributed to and in many ways are the outcome of dialogue and collaboration among American and Japanese researchers. It is no accident then that the terms coordination and comparative are employed throughout the book. What are presented are comparative analyses of how these two economies function and what opportunities and constraints they present for enhanced cooperation.

It is certainly not new to say that there are differences between the American and Japanese economies. What is needed, however, is serious and sober analyses of which differences make a difference. That is what is undertaken here, with special reference to the broad issues of economic, industrial and managerial coordination between Japan and the US, whether and how the US and Japan can improve their existing coordination, and the direction and form this coordination can take.

There will be difficult periods in the 1990s when the differences between the two countries put some strain on their economic relationship. These will be unhealthy for both countries and a major problem for many other countries. Realistic perspectives on how to manage both shared interests and differences will be the key to minimizing the occurrence and consequences of these difficult periods.

One step in that direction is this book. There will be a continuing need, however, for many similar steps, based on serious scholarship, open dialogue, and shared assessments of needs and possibilities.

SeiJi Naya

Professor, University of Hawaii and East-West Center 


\section{Acknowledgements}

CHIBAMA acknowledges the generous support of the Ministry of Education (Monbusho) in Japan for the realization of the three-year university-to-university joint research project.

CHIMBAMA also acknowledges the support of the East-West Center for co-sponsoring the third CHIBAMA conference.

The editors wish to express their appreciation to all those who have assisted in the preparation of this book, especially Lori Hall, Patty Nelson, Annette Watters, Sherry Price and Theresa Welch White.

Kiyoshi Abe William GUNTHER Harold See 


\section{Notes on the Contributors}

Mohamed Abdel-Ghany is Professor of Consumer Sciences and Director of International Affairs for the College of Human Environmental Sciences at the University of Alabama. He holds a PhD in Family Economics from the University of Missouri and a masters in Economics from Iowa State University. His research interests include consumer and family economics. He has published over sixty articles in various journals and proceedings. $\mathrm{He}$ is a consultant to the Agency for International Development, a member of the Journal of Consumers Research Policy Board, Chairman of the Home Economics Research Journal Policy Board and members of its Panel of Reviewers, and a member of the Board of Directors for the American Council on Consumer Interests.

Kiyoshi Abe is Professor of Economics at Chiba University, Japan, where his major field of research is international economics, and was Visiting Professor at the University of Alabama (1990-1). He received his PhD from the State University of New York at Binghamton in 1970, and taught at Sophia University International Division, Tokyo (1970-4) and at Takushoku University, Tokyo (1974-87). He has also been a Research Fellow at Kiel Institute of World Economics in Germany (1976-7) and a Research Economist at Hitachi Information Systems Laboratory (1970-5). He has published "A Comparative Study of the Economic Development and Debt Problem of Asian and Latin American NICs", in H.W. Singer and S. Sharma (eds), Economic Development and World Debt (Macmillan, 1989), and many other articles.

Shigeyuki Abe is Professor at the Research Institute of Economics and Business, Kobe University, Japan. He obtained his BA from Osaka University, Japan, and holds an MA and PhD from the University of Hawaii. He has been associated with the Resource Systems Institute, East-West Center, since 1988. He has been working in the area of development, modeling and international trade of Asian countries in their relation with Japan. His recent publications include "Competitiveness and Exchange Rate Adjustments in Korea" in Development \& South-South Cooperation (1989) and "A CGE Analysis of Income Distribution: The Case of Malaysian Economy", Asian Economic Journal (1988). 
Trevor Bain is Professor of Economics at the University of Alabama where he is a labor economist specializing in industrial relations. He was educated at the City College of New York (BA), Cornell University (MILR) and the University of California-Berkeley (PhD). He is the author of more than fifty publications and has received research grants from the Ford Foundation, the United States Department of Labor, the National Science Foundation and, in 1989, was named a Rockefeller Foundation Scholar. His latest work is Banking The Furnace: Unions, Job Security, and Restructuring of the Steel Industry in Eight Countries.

James Cashman holds a $\mathrm{PhD}$ from the University of Illinois. He is Professor of Management at the University of Alabama, where he specializes in leadership, group dynamics and organization development. He is a member of both the American Psychological Association and the Academy of Management. He has published extensively in both psychology and management journals.

David Cheng is Professor of Economics at the University of Alabama. He studied at the National Taiwan University and Yale University from which he received his $\mathrm{PhD}$ in Economics in 1973. He is a member of the American Economics Association, the Econometric Society, the American Statistical Association and the Financial Management Association. He has published numerous articles.

Marilyn B. Emplaincourt earned her PhD in French from the University of Alabama in 1977. She has served as University of Alabama Program Coordinator of International Programs since 1980 and as Interim Director of the Japan Program since 1986. She was instrumental in inviting JVC Corporation to Tuscaloosa in 1986, and helped develop the Japan Culture and Information Center. She leads the annual state-wide Sakura Festival and many other international Japan-related events. She serves as a director of the Japan-America Society of Alabama and of the Southeast Association for Japanese Research, among other internationally-oriented organizations.

Lawrence W. Foster is the John R. Miller Professor of Management at the University of Alabama. His $\mathrm{PhD}$ is from the University of Texas. His research interests are strategy formulation, US competitive position in global markets and Japanese industrial strategy. He has written extensively, is editor of Advances in Applied Business Strategy, and is acting director of the University's World Business Program.

William Gunther is Associate Dean for Research and Service, Director of the Center for Business and Economic Research and Professor of 
Economics in the College of Commerce and Business Administration at the University of Alabama. He received his $\mathrm{PhD}$ from the University of Kentucky. He has research and publication interests in regional economic development issues. He has received two Fulbright Awards (Mexico and Brazil) and has served as a Visiting Fellow at the University of Sussex (England). Dr Gunther was a co-founder and past officer of the Southeast Association for Japanese Research.

Chadwick B. Hilton is Assistant Professor of Management Communication at the University of Alabama. His teaching and research interests include cross-cultural and international business communication, advertising language, and written business communication. He has conducted professional development programs on written business communication and Japanese Management.

Donald Hooks is Associate Professor of Economics and Director of Graduate Programs in the Department of Economics, Finance, and Legal Studies at the University of Alabama, where he has been a member of the faculty since August, 1971. During the 1980-1 academic year he was a Visiting Scholar in the Research Department of the Federal Reserve Bank of St. Louis. His areas of current research interest include Monetary and Financial Economics, Market Structure and Performance, and International Monetary Policy Coordination. In addition to a number of articles on these and other topics in refereed journals, he has published monographs and research reports on regional economics, energy economics and benefit-cost analysis.

Meheroo Jussawalla is a Research Associate/Economist at the EastWest Center and Affiliate Faculty in the Department of Economics, University of Hawaii. She has been a Visiting Scholar at the Institute of Social and Economic Research, University of Osaka, Japan. As a leading scholar in the economics of telecommunications, her recent publications include The Calculus of International Economics: A Study in the Political Economy of Transborder Data Flows, The Cost of Thinking: Information Economies of Ten Pacific Countries, Communication and Information Economics: New Perspectives and Information Technology and Global Interdependence. She serves on numerous communicationsrelated advisory and editorial boards, and was the 1990 recipient of an award from the Women in Communications Association.

Kenji Komatsu received his $\mathrm{PhD}$ from Waseda University, and is Professor of Economics on the Faculty of Law and Economics at Chiba University. Before joining Chiba University he was a Researcher at the Institute of World Economy. He has been a Visiting Scholar at 
UCLA and an Honorary Research Associate at Harvard University. Among the books he has written are The Japanese Economy: Conditions for the Conquest of Stagflation and The American Economy: Substance of the Crisis.

Bruce Koppel was educated at Rutgers and Cornell Universities where he completed studies in history, comparative politics and rural sociology, with a focus on Southeast Asia and East Africa. His special area of country expertise is the Philippines where he has twice been a visiting professor. He joined the East-West Center in 1973 and has developed a wide variety of programs and projects on issues of economic development, regional cooperation, political change, and technological innovation in the Asia-Pacific region. He is the author of over a hundred articles, reports, and books on a wide variety of subjects. In 1991, he was named interim director of the East-West Center Institute for Economic Development and Policy.

Sumner J. La Croix is Professor of Economics at the University of Hawaii, Honolulu, and a frequent participant in East-West Center programs. He received a $\mathrm{BA}$ in mathematics from the University of Virginia in 1976 and a $\mathrm{PhD}$ in economics from the University of Washington in 1981. He has held visiting positions in New Zealand, Australia and China. His research focuses on the development of property rights in land, natural resources and intellectual property in Asia and the Pacific. La Croix's work concentrates on how and why property rights and other social institutions change in response to external and internal challenges and innovations.

Charles E. Morrison is concurrently coordinator of the International Relations Program at the East-West Center, Honolulu, and a senior research associate with the Japan Center for International Exchange in Tokyo. He received his PhD from the Johns Hopkins School of Advanced International Studies, and worked from 1972 to 1980 as a legislative assistant to US Senator William V. Roth, Jr. He served as a research advisor to two binational commissions, the Japan-US Economic Relations ("wisemen") Group and the US-Japan Advisory Committee.

Motofusa Murayama is Professor of International Management on the Faculty of Law and Economics at Chiba University. His teaching and research have centered on international comparative management and organizational sciences with emphasis on the USA, Europe, South East Asia and Japan. He is the author of many books, including: Introduction to Asian Management, Japanese Management Theories, The Japanese 
People and Management, Cultural Theory of Japanese Management, Theory of Overseas Management Transfer, Nation Building and International Management, and Convention Management Strategy.

Barbara Ross-Pfeiffer is a PhD candidate and is a lecturer in Economics with the College of Continuing Education at the University of Hawaii and Kapiolani Community College. She was formerly a Project Assistant with the Institute of Culture and Communication at the East-West Center.

Harold See is Professor of Law at the University of Alabama School of Law. He received his MS in economics from Iowa State University and his JD from the University of Iowa. He specializes in intellectual property, law and economics, and alternative dispute resolution. He has authored a number of articles on intellectual property and on law and economics and has books forthcoming in both areas. His abiding interest in Japan can be traced at least to his 1982 article "The Judiciary and Dispute Resolution in Japan", Florida State University' Law'Review'.

Deanna L. Sharpe is Assistant Professor in the Department of Consumer Sciences at the University of Alabama. She has a PhD in Family Environment and a masters in Economics from Iowa State University. Her research interests focus on effective allocation and use of time and money across the family lifecycle.

Hisayo Shima is Professor of Economics for the Faculty of Education at Chiba University. Her masters in economics is from Hitotsubashi University. Her research interests include demand forecasting, consumer economics, international comparison of consumption and economic education. She has published a two-volume book on international understanding in the classroom. She is a member of the Japan Statistics Society, Theory \& Econometric Society, Measurement of Behavior Society and International Education Society. She is a member of the Board of Directors of the Research Council on Economic Education.

Yasuhiko Yuize is a graduate of the Faculty of Economics of the Tokyo University, and also received an MA degree in economics from the University of Chicago. He worked for thirty years as a researcher for the National Research Institute of Agricultural Economy, the Ministry of Agriculture and Fisheries, and now is a Professor on the Faculty of Law and Economics at Chiba University, where he served as Dean of the Faculty from 1989 to 1991. 